\title{
Citizenship, marginality and urban (in)security in contemporary Africa: introduction
}

\section{Kieran Mitton and Ibrahim Abdullah}

Abstract: We introduce four contributions to this special issue exploring insecurity in contemporary African cities, drawing on case studies from the Democratic Republic of Congo, Ghana, Somalia, and South Africa. We problematise alarmist and decontextualised discourses surrounding Africa's rapid urbanisation, identifying common findings across empirically rich contributions ranging from gangs and vigilantes to migration, mobile phone technology, and community (dis)connections to basic services. We show that marginal residents traverse blurred boundaries between formal/informal, legal/illegal, and acceptable/subversive in their quotidian struggle for survival, arguing that by reifying rather than reducing structural inequalities, Africa's growing cities force many into 'insurgent' forms of citizenship. Importantly, this is rarely entirely oppositional or supportive of the state and status quo: it occupies ambiguous social space as both resistance and collusion. The complicity of some state elements in producing transgressive or informal modes of urban governance and services underlines our key conclusion: addressing Africa's urban insecurity requires political change: technological and infrastructural progress alone is insufficient.

Keywords: City, citizenship, contestation, insurgent citizenship, marginality, transgressive citizenship, social movements, urbanisation, Africa.

Notes on the authors: Ibrahim Abdullah is a Professor of History at Fourah Bay College, University of Sierra Leone. His current research project deals with youth street gangs in contemporary Sierra Leone/ Africa. His most recent publications are: (2020), 'Marginal Youths or Outlaws: Youth Street Gangs, Globalisation, and Violence', African Development, 45(3): 33-52; (2020), 'Reading History From the Bottom Up-From Citizen and Subject to Neither Settler Nor Native', CODESRIA Bulletin, 4: 44-8.

Kieran Mitton is a Reader in Conflict, Security and Development in the Department of War Studies, King's College London, and cofounder of the Urban Violence Research Network. He conducts fieldwork with perpetrators of violence and affected communities in Sierra Leone, South Africa, and Brazil. He is the author of 'A Game of Pain: Youth Marginalisation and the Gangs of Freetown', forthcoming, Journal of Modern African Studies, and Rebels in a Rotten State: Understanding Atrocity in the Sierra Leonean Civil War (Hurst/OUP, 2015).

kieran.mitton@kcl.ac.uk

(C) The author(s) 2021. This is an open access article licensed under a

Creative Commons Attribution-NonCommercial-NoDerivs 4.0 Unported License 


\section{Introduction}

In the early 21 st century, humanity crossed a threshold to become a primarily urban-dwelling species for the first time in its history. Over recent decades, a series of predictions for the near future have provided jaw-dropping statistics that point to unprecedented growth in cities. Such forecasts have fuelled a resurgence of work that has sought to revisit fundamental questions concerning human security and development, reviving Malthusian debates over the potential impacts of mass migration, resource scarcity, and over-population. What challenges, alongside the many benefits, does urbanisation present? Where will these be felt most acutely, and how might they be met?

Africa has the fastest-growing urban population in the world; it grew from 27 million in 1950 to 567 million in 2015 (OECD 2020: 14). By 2050, sub-Saharan Africa is expected to add a further 1 billion to the world's population-more than half of the world's predicted total growth - with most of that growth absorbed by cities (UN DESA 2019: 1, 37). It is little surprise then that Africa stands at the forefront of concerns over rapid urbanisation.

In many respects, the challenges of rapid urban growth are already being felt in the world's youngest continent. Media reporting of Lagos, Nigeria - the go-to examplehabitually warns of the potentially dire consequences of the mega-city's unchecked urban growth (for example, see Princewill 2021; Vidal 2018). Already estimated to comprise a population of between 15 and 21 million in 2021, most predictions expect Lagos to double in size by 2050 and it could ultimately become the world's largest metropolis, prone to flooding, criminality, and in large swathes ungovernable. Unlike in other parts of the world, urbanisation in Lagos shows no sign of slowing. Growth has been largely unplanned, driven by rural-to-urban migration, and epitomised by booming informal 'slum' communities (Gandy 2006). This is where the majority of the young urban population live, eking out their survival through informal economic activities. Is this the fate of African cities and their residents?

The defining characteristic of much reporting and scholarship on African urbanisation is the stark observation that, unlike in many parts of the northern hemisphere, the cities in sub-Saharan Africa have grown much faster than their infrastructure (UN DESA 2019: 3). In fact, urbanisation has taken place without the benefits of economic and infrastructural development, and so, the warnings go, Africa's urban future is one fraught with risks (Hove et al. 2013). Already, 189 million sub-Saharans live in the continent's slums where they experience pronounced disparities in life expectancy, health, and well-being (UN DESA 2019: 4). Gaps between the rich and poor, the elites and the marginalised, may grow wider; African cities may become bifurcated worlds of downtown high-rises surrounded by sprawling, ungovernable slums. 
While scholarship is increasingly turning to the question of how Africa is being affected by urbanisation, and the articles in this issue are a part of this contribution, there remains a tendency to approach this topic through reductive pre-set frames that have long characterised analysis of Africa. Peace and conflict studies, for example, have tended to remain state-centric and overlook urban insecurity when not directly linked to civil conflict or armed groups. This is epitomised in the Eastern Democratic Republic of Congo (DRC), where - as Hendriks (2021) notes in this issue - analysis typically reproduces a 'standard imagery of violence', which views it as taking place in rural areas, involving armed groups. This has led to pronounced neglect by peacebuilding research of significant forms of insecurity and everyday criminal violence affecting urban Eastern DRC (see also Verweijen 2019). Recent work on Sierra Leone bears similar findings: a preoccupation with peacebuilding and 'post-conflict' discourses has left the growth of street gangs largely untouched by scholarship and policymakers (see Abdullah 2020; Mitton forthcoming).

A related challenge in scholarship and reporting is the almost reflexive default to urban pessimism, with discussion intersecting with concerns over the so-called 'youth bulge' and neo-Malthusian predictions of criminal anarchy, following Robert Kaplan's infamous 1994 'The Coming Anarchy' essay. As such, urban pessimism has tended to converge with Afro-pessimism to paint nightmarish pictures of sprawling African slums, rife with disease and danger (Warah 2011). A major criticism of much of the environmental security and New Barbarism work of the 1990s was its tendency to depoliticise conflicts and contexts in favour of a reductive material determinism, compounded by dehumanising portrayals of marginalised youths. In focusing on the material impacts of urbanisation, particularly of resource scarcity, climate change, and migration, much recent literature may be challenged for the same tendency: vitally important underlying social and political conditions are frequently obscured. Forms of informal order and bottom-up governance are missed due to a fixation on state absence and use of misleading catch-all terms such as 'ungoverned spaces'. What has been lacking in such accounts is deeper engagement with and understanding of local historical, social, and political conditions across Africa's varied urban spaces.

More nuanced analysis need not gloss over the challenges that urbanisation presents (see for example Olajide et al. 2018). Indeed, it would be equally reductive and misleading to reimagine African cities as uniform engines of progress and development. Rather, analysis can help to better qualify the challenges, countering the tendency to essentialise insecurity and under-development as an inherently African problem for which few solutions can be found. As with cities across the globe, African cities are both potential drivers of economic development and sites at which pronounced inequalities and political fault lines come into stark relief. A glimpse of the cities under discussion in this issue will quickly dispatch any inclination towards naive urban optimism. These contributions provide empirically anchored insights into the 
everyday challenges that exist in cities across Africa. They temper optimism around urban development (including technological progress - see Chonka \& Bakonyi 2021) by exposing the extent to which urban trajectories are intimately tied to underlying political and social structural configurations, which growth may entrench rather than challenge. In its detailed exploration of cases from Ghana, the DRC, Somalia, and South Africa, this issue contributes to addressing the lacuna in knowledge of how contrasting African urban spaces affect everyday security and development for their citizens, and how cities and 'citizenship' are being made and remade by those surviving on the margins (Holston 1999; Simone \& Abouhani 2005; Brown 2015).

\section{African cities and contested citizenship}

The increase in population, largescale rural-to-urban migration, and rapid urbanisation and proliferation of mega-cities - all post-colonial markers - continue to shape and re-shape African cities in complex and contradictory ways. If urbanisation had historically hinged on economic growth and rapid industrialisation, the veritable push factors that arguably made that equation possible in the Global North have not been replicated nor reproduced in the Global South. This unintended decoupling of urbanisation from economic growth and industrialisation has resulted in the growth of a ballooned parallel economy, the now infamous informal sector, within which the ever-increasing numbers of migrants to Africa's booming cities make their living. Thus, the 'size of the city's economy', Mike Davis pointedly observed, 'often bears surprisingly little relationship to its population size' (Davis 2006: 13). It is within this crucible of a ballooned parallel economy alongside a formal economy, not tied to the creation of employment, that the struggle for citizenship in Africa's numerous cities takes place (Cooper 1983). How this struggle unfolds in the single city nation, as in Sierra Leone or Botswana, compared to the mega-city nation, as in Nigeria or South Africa, is immaterial (Freund 2007). In the words of the youths who constitute the bulk of those who troop to Africa's numerous cities - those who subsist cheek by jowl in informal settlements without modern amenities-life has become an intricate activity centred on the existential reality of se debrouillage /desenrascar a vidal getting by (Honwana 2012: 4, 62, 86). ${ }^{1}$

It is this hustling in the city - from Accra to Baidoa from Durban to Kivu - which connects all the interventions in this special issue. And these four interventions reveal disturbing aspects of what the city has become all over Africa: swathes of urban spaces occupied by city dwellers who rent them out to migrants struggling to become

${ }^{1}$ For a comprehensive survey of African cities see the following: Mabogunje (1990) and CoqueryVidrovitch (1991). The most recent survey is Freund (2007); see also Simone \& Abouhani (2005). 
insiders/citizens, as in Somalia; well-to-do shopkeepers, struggling hawkers, and affluent traders, willing to finance a counter-force, the anti-gang, to protect them from maibobo (street boys) who rob and assault them, as in Goma, Eastern DRC; citizens on the edge in post-Apartheid South Africa who cannot access the wherewithal of modernity, water and power supply, except by subverting the normative order of civilised society; and in Ghana, party toughs, financed and supported by leading politicians, masquerading as an alternative to state apparatus to protect sectional party interests. These all too familiar transgressive instances reference the conundrum that is contested citizenship in contemporary Africa and lay bare this existential reality in a crucial site, namely the city, the very abode where citizens are consistently being made, remade, and unmade (Holston 1999: 3-7). The making and unmaking of citizens and citizenship, with and without rights, constitutes the story of African cities writ large.

Thus at issue here are the overlapping public concerns of security, law and order, and the ultimate authority of state officials. Multiple transgressions as in the case of the maibobo invoke the total breakdown of formal law and order and the acquiescence by state officials of an alternate order: 'street authorities' that take over, if only temporarily to replace an errant state. Such concessions from above, if not total abdication, underline the informality and extralegality that defines and even rules over certain urban spaces in contemporary Africa. That the anti-gang machine could offer protection and also punish 'offenders' speaks to the existence of multiple areas of counter-authority in Africa's insecure urban spaces that are subjected to multiple contestations. Similarly, the illegal electoral and security role of vigilantes in Ghana's deadly bi-polar politics, a four-year do-or-die ritualised performance around powerthe electoral contest between the National Patriotic Party (NPP) and the National Democratic Congress (NDC) — could be read as a brazen attempt to re-make order and 'legality' in their own interests by subverting state authority during the democratic electoral cycle. As in the Kivu case, such subversive acts are undertaken with the consent of certain state officials who recruit and arm these men, and in both cases the intervention is not intended as a replacement of legitimate authority. Rather, they are instances of tempo-spatial displacement of constituted authority in favour of subaltern interests in alliance with officialdom from above. Such subversive interventions not only undermine state authority but also create patronage openings for marginal actors with sectional interests aligned to state officials. Subverting the law has become a normative pathway to another form of citizenship - subversive, or insurgent-in contemporary Africa (Brown 2015; Holston 2008).

There is room here for disorder - an underlying feature of most African cities, from Lagos to Kinshaha to Brazzaville and Johannesburg. If state officials in Ghana refuse to accept the findings of a legally constituted commission of inquiry, set up to probe the activities of a security outfit that operates outside the law, what does this tell us about the state and the rule of law? And if informal settlement dwellers in South 
Africa court assistance from bona fide power sector workers to assist in providing 'legitimate' power and water connections, what does this say about bottom-up transgression to access basic human needs? Here are two examples of transgressions from above and below - the Ghanaian state disavowing its own findings in favour of sectional party interests and citizens in South Africa transgressing to access basic human needs. The city is not only the veritable site where the acceptable and unacceptable overlap and play out, irrespective of the normative order; it is also the milieu where state officials switch sides to undermine or re-shape the normative order from above. Understanding the subversion of the normative order from above is therefore central to understanding the dynamics of subalternity from below.

\section{Barriers to belonging and connection}

In each of the articles in this issue, we are moved to consider the nature of belonging in the modern African city and question how such key terms as citizenship, (dis)connection, and legitimacy are understood, achieved, and contested. It is clear that paradoxes and ambiguities abide in many of these terms. In her study of vigilante groups in Accra, Bjarnesen (2021) notes that young party soldiers tend to be drawn from marginalised sections of the population; their political mobilisation is an attempt to connect with political patrons who might bring them closer to participation in mainstream social and economic life. Their frustration at broken promises shows that, perversely, the result of their labour is typically greater marginalisation as they are demonised as a threat to national security. Nevertheless, they often do achieve a degree of 'local legitimacy' as they cast themselves as protectors of the community. In his discussion of the anti-gangs of Goma, Hendriks (2021) likewise carefully unpacks the self-image of members - similarly drawn from among marginalised youths - as they portray themselves as protectors of local communities against everyday crime and violence committed by the maibobo. They claim legitimacy both as providers of security and as watoto ya Goma (children of Goma) - a more easily acquired notion of local citizenship than origin-based 'sons of the soil' that incorporates the diverse origins and ethnicities of the urban poor, which is a dynamic seen elsewhere in Africa (Diouf in Holston 1999).

In the cities of Baidoa, Bosaaso, and Mogadishu, the issue of belonging and connection is critical to the survival of the displaced in the new urban Somalia. Chonka \& Bakonyi (2021) explore the ways in which these populations, defined in many respects by their marginality, utilise mobile phone technology to mitigate these challenges, connecting to social and financial networks locally as well as globally. However, their interviews with those on the margins reveal a critical point: possession of a mobile phone alone does not automatically empower the socially excluded. Essential here, 
and across the cases discussed in this issue, are the underpinning social relations, power differentials, and economic and political constraints that may act as barriers to attempts to connect and overcome marginality. The transformative potential of new technologies, as with urban growth more broadly, is contingent on more fundamental political change.

In Durban, South Africa, notions of citizenship and belonging are linked directly to access to basic services. Mottiar (2021) shows us that a legacy of resistance to Apartheid remains in the perceptions of Umlazi township residents that access to water and electricity is more than simply a means of survival; it is a means of claiming 'genuine citizenship'. The case of Umlazi impels us to question not only the legitimacy or legality of 'insurgent' self-connecting to utilities, but also the very legitimacy of the state that may itself represent a barrier to belonging or connection. As Schnitzer (2016) has demonstrated in her study of 'Democracy's Infrastructure', the denial of poor citizens' access to basic necessities like water takes several forms in South Africa: from the introduction of water meters to the non-existence of legal connection because of residents' inability to pay. Likewise, the local legitimacy claimed by, and in many respects afforded to, self-imposed 'street authorities' cannot be understood without reference to the perceived failures of the state and establishment. In Accra, Bjarnesen (2021) notes that public support for vigilantism often reflects popular resentment over the perceived procedural injustice of the nation-state and its legal apparatus. Likewise in Goma, when talking about state security services an anti-gang member puts it simply to Hendriks (2021): 'we are there because they fail'. The failings or sheer absence of the state is not only the central issue around which the Somali case revolves; it is also the key variable that unites all the cities examined in this special issue. Thus, for the ubiquitous marginalised population, taking action, whether as self-protection or self-connection, becomes a means of both mitigating and resisting the neglect of the state.

This issue also cautions against taking the failures of the state as evidence that informal and illicit actors are purely oppositional; each context belies a far more ambiguous situation than state versus non-state, formal versus informal authority. The cases from the DRC, Ghana, Somalia, and South Africa show that these boundaries are fluid and often blurred. Goma's anti-gangs do not so much propose a new political order as seek to be included within it; their collaboration with the law suggests their yearning for inclusivity. Similarly, Accra's vigilantes may often challenge the state and the rule of law, yet they occupy an ambiguous space in which the establishment is complicit in, and seeks to prosper from, their activities. In both contexts, marginal urban youths do not seek revolution so much as escape from their marginal status and incorporation into the mainstream of political life. In rejection of their exclusion, urban actors in the cases discussed in this issue seek to change, rather than replace, the political status quo that has marginalised them. Drawing on Foucault in 
her discussion of self-connecting in Umlazi, Mottiar (2021) brings this out through the lens of 'counter conduct', helping us to see how illegal actions by residents should be understood as forms of subdued protest and resistance.

\section{Contesting marginality}

Multiple transgressions define the activities or way of life of subaltern/marginal citizens in African cities, and subverting the normative order constitutes a key pathway to contesting marginality in their everyday existence. This 'counter conduct' to use the Foucauldian framing should not be read as implying that subalterns/marginals are inherently criminal, but rather that making a living or eking an existence in the ballooned informal sector without license, without 'owning' a shack in an informal settlement, or without power or water supply, seemingly puts one outside the law. Internally displaced individuals in Somalia's urban landscape inevitably crisscross the legal and the illegal unconsciously in their everyday life. Marginals are therefore those whose existence compels them to embrace a mode of making a living in the city not built for them that borders on transgression. This is conveyed to varying degrees in all the case studies here: maibobos and the anti-gang in Goma, Eastern Congo; vigilantes in Accra; internally displaced city dwellers fleeing from drought, war, and poverty in Baidoa, Mogadishu, and Bosaaso; and urban residents below the poverty line in South Africa.

There are many forms of contestation covered in this issue, among them the striking adoption or idealisation of forms of hypermasculinity surrounding assumed rebel identities: the insurgent, the bandit, the gangster. In Ghana we meet the 'macho men' who trade their capacity for violence for political sponsorship, an attempted counter to poverty, powerlessness, and marginality (Bjarnesen 2021). In the DRC, as in many urban contexts around the world, we find similar notions surrounding hypermasculinity among the anti-gang members, who seek to embody and practise the strength, fearlessness, and fearsomeness of martial artists and heroes from action movies. Yet Hendriks (2021) deftly shows us that the popularity and identification of some marginal urban youths with these ideal rebel figures is not simply about their capacity and reputation for violence, though it is certainly a significant factor; they are also symbols of restraint, discipline, paternal protective care, and self-control in a treacherous and disorderly world. Once again, we find that the ways in which urban insecurity affects and shapes identity, including around the expression and reimagining of gendered roles, refuses simplistic reduction. This sensitivity to nuance is strongly conveyed in Chonka \& Bakonyi's (2021) discussion of the relationship between mobile phone ownership and gender, both in Somalia and more broadly. Whereas hypermasculinity may be instrumentalised by youths to escape or challenge exclusion in Accra 
and Goma, in cities such as Mogadishu, Baidoa, and Bosaaso, gender norms may severely deepen the marginality of internally displaced women and girls. While mobile technology may be seen by external humanitarian actors as a potential way to overcome, or at least contest, structural gender inequalities and power imbalances, placing the world - and in particular, access to financial services - into the hands of marginalised urban African women, the voices of such women tell a different story. Use of phones, and access to the knowledge required to operate them, is itself gendered and often exclusionary. Phones can extend forms of control and surveillance of women by male family members and partners, and as Chonka \& Bakonyi's interviewees recount, some internally displaced women may be more likely to go unpaid for their work-a matter of surviving pronounced precarity - when receiving payments over a mobile phone rather than in person. This research thus underlines the importance of listening closely and carefully to what those living on the margins have to say about how they do, and do not, contest their marginality.

Acts of resistance by subalterns are hardly ever seen or interpreted as such-this no doubt constitutes a fundamental flaw in our understanding and interpretation of the individual and collective actions of those whom history might rather forget. Their actions, subtle but not so subtle responses, the stuff of infra-politics, are occasionally dismissed as weapons of the weak. Others are labelled acts of criminality because they challenge established norms and regulations by stretching the boundaries of what is acceptable in society (Thompson 1993; Scott 1990). Their existence in the informal sector, and in some instances as groups of neighbourhood 'toughs' organised to patrol the market and provide protection for traders, may not sit well within the norms of society but is accepted in certain contexts where state power is on the retreat and insecurity is rife. Similarly, a political party in power may allow their 'macho men', as in Accra, Ghana, to flex their muscle in furtherance of party interests in an electoral competition so as to access resources and job opportunities. And citizens in informal settlements would bind together to undo their collective marginality by forcefully accessing water and electricity as of right. Even displaced urban dwellers in Baidoa and Mogadishu might assert their individual and collective right to a decent life in a precarious context in a way that begins to question established norms in their favour.

This transgressive milieu within which marginal and not so marginal actors operate is a spatial context within which the legal and the illegal coalesce in a fusion that is not always easily understood. This quotidian swing, traversing the legal and the illegal, the unacceptable and the acceptable, defines the everyday life of the subaltern or marginal in Africa's cities. Boxed to the periphery, mostly in informal settlements without basic amenities, power and water, sanitation and good roads, schools and hospitals, their existence is individually and collectively contoured by acts that seemingly border on the unacceptable. Thus, they are housed in informal settlements without title deeds; they access basic necessities, power and water, via the back door; and 
they engage in illegal activities to garner votes for their political parties. Their continued existence in such precarious circumstances raises fundamental questions about the state in which they live and how they get by and continue to reproduce themselves. Precarity, as profoundly clear in the case of Somalia, defines their everyday existence.

A cursory examination of the historicity of the state in these four case studies would complicate the narrative - none of these countries are similar in terms of citizens' rights and state functions. From the extreme there is Somalia and the Congo on the one hand, and Ghana and South Africa on the other. Somalia and Congo have been going through a period of extended state and societal crises during which the state ceased to function in the capacity of a state in particular periods of its existence and in certain areas within its boundaries. Thus, whereas Somalia had been partitioned, and the state ceased to exist in the sense of performing its basic function of law and order, the Democratic Republic of Congo remained as a single entity but with certain regions existing as semi-autonomous entities within the Congolese nation-state. The seeming disintegration and lack of a central authority does affect citizens' livelihoods and responses to occurrences in their immediate environment. This post-colonial trajectory provides the context within which the maibobo and its counter-force, the anti-gang, evolved. It also underlines the consequent actions of citizens in exercising their alleged rights within the constraints of a seemingly distant and occasionally non-existent state. Here then is the ideal context for deprived citizens to stretch their actions in making sense of their everyday existence in the absence of a legitimate state authority.

Ghana and South Africa arguably exhibit more functional states with control of their territory, law, and order, but riddled with the obvious shortcomings of non-functional liberal democracies in which those on the periphery do not get to share in the dividends of democracy. The South African state is still grappling with the legacy of Apartheid, and the ANC government is widely seen by its citizens as having woefully failed to right the wrongs of the Apartheid state in material terms. This failure has in turn provided the justification for popular claim-making by Africans around meaningful citizenship in their individual and collective existence (Mottiar 2021; Brown 2015). Their individual and collective resistance, subversive 'counter conduct', could therefore be read as acceptable and legitimate even as they transgress the borders of the unacceptable in accessing basic amenities as of right.

The Ghanaian situation is completely different. Here, in the name of democracy the two major parties have set up similar extra-judicial outfits to provide protection during their competitive four-year electoral cycle. The formation of so-called vigilantes by both parties was clearly outside the normative design. Even so there were contested claims and counter-claims to justify their existence even when their names and modus operandi were a giveaway - they were political gangs established outside the law in the service of their respective parties (Bjarnesen 2021). The NDC had the 
Azorka Boys and the NPP had the Bolga Bull Dogs; both claimed they were legitimate party outfits and refused to disband. Here were two parties alternating in governing a state but with no faith in the neutrality of the security apparatus that supposedly exists for the common good. Even when a commission of inquiry's findings ordered that these vigilante groups should be disbanded, in conformity with the established rules, both parties refused.

Maintaining these groups not only empowered the 'macho' urban youths who were recruited and armed by politicians but it also underlined the multiple and conflicting pathways within which marginal youths could access power and patronage by subverting the laid-down democratic process. They therefore embrace the unconstitutional party apparatus to challenge their individual and collective marginality. Operating outside the normative boundaries was clearly socially unacceptable, as articulated by the commission of inquiry; yet, as articulated by those in positions of power and influence who had mobilised them, it was politically tolerable and practically doable because they could get away with it.

\section{Structure versus agency: from transgressive to insurgent citizenship}

Displaced citizens eking out an existence on the edge of cities in war-affected nations; gangsters offering protection to merchants constantly harassed by street crime in which the local regular police are arguably complicit; marginal youths aligned with unscrupulous politicians, playing political musclemen and openly violating laid-down rules and procedures; and the peri-urban poor in makeshift abodes, struggling to access the wherewithal of modernity - power supply and drinkable water: what all these disparate actors tell us about the nature of the state, security, and law and order in the city is not unique to Africa. These subaltern actors individually and collectively reference occurrences that have come to symbolise the fallout from globalisation and the now dominant neo-liberal order (see Holston 1999; Armano et al. 2017). It is doubly important that these are voices from below - those who are left out, who subsist on the margins, and who employ alternative means to make their voices heard - those knocking on the door of modernity, asking to be allowed to participate as citizens.

Modernity defines and re-defines the city, the abode of the citizen where citizenship has become an intense everyday struggle for the basics of life. Cities are where employment is available, where modern health services are more easily accessed, where education, at whatever level, might be obtained, and where cultural activities are concentrated (Salahub et al. 2018). Cities are also the central hub of economic growth generating approximately 80 per cent of global GDP (Salahub et al. 2018: 1). In the context of the Global South this translates into a socio-economic powerhouse, a gigantic magnet that attracts migrants from within and across nations. The 
UN-Habitat, the key institution within the global body responsible for urbanisation, records a staggering 3 million souls migrating to cities in the Global South every other week (Salahub et al. 2018: 1). This mass movement to cities in Africa and Asia is as much the product of internal dynamics within specific nation-states as the product of the overarching external dynamics keyed to globalisation and neo-liberalism in the Global North.

Thus, the impact of globalisation and the hegemonic stature of neo-liberalism as the only viable vehicle to modernity have conduced to form a complex structuration from above that continues to generate poverty, precarity, and crisis in Africa and other areas of the Global South. Structural adjustment policies in Africa have reconfigured development in complex ways that privileges the market against human needs; and market dogma against basic needs now contours everyday life-from education to health to sanitation to infrastructure and housing. Put differently, Africa entered the 21 st century at a time when a new global order had enveloped the world in the aftermath of the collapse of the Berlin Wall. This period also coincided with the rolling out of a new liberal democratic project popularly referred to as the second wave of democratisation (see Young; Bates; Van de Walle; Mkandawire in Joseph 1999). It is to how neo-liberalism has reconfigured the political economy of Africa, and how and why the expected growth rate has not translated to trickling prosperity for Africa's growing youth population and urban poor that we must now turn.

The overarching precarity, which the market-driven ideology of neo-liberalism generates, connects easily to Africa's already ballooned informal economy. The massive retrenchment occasioned by structural adjustment has not only streamlined the traditional working classes but has also affected the multiple ways in which labour could flex its muscle or engage capital. ${ }^{2}$ So many of Africa's impoverished pastoralists and retrenched workers have headed to major cities in search of making a living. The urban insecurity that this kind of movement generates is visible across contemporary Africa - from Nairobi to Lagos to Addis Ababa to Bamako to Johannesburg.

To understand this trajectory in contemporary Africa we draw on urban theorists who have explored the intersection between urban marginals seeking to access housing, education, health, and other wherewithal of modernity in Africa's cities, and the broadening of those existential struggles around basic rights and entitlements in the city in the form of social movements. From Asef Bayat's notion of the 'quiet encroachment of the ordinary', focusing on everyday forms of resistance in Tehran, to James Holston's insurgent citizenship in Brazil's major city, Sao Paulo, where the housing issue became a central pillar in the struggle for citizenship, we see a bottom-up movement around which social movements emerge to unsettle the urban space by

2 The traditional labour unions are only active in few countries in contemporary Africa-Nigeria, South Africa, Egypt, and to a lesser extent Tunisia and Kenya. 
agitating for basic rights as citizens (Bayat 2010; 1997; Holston 2008). Here, defiant and popular agency from below confront and occasionally unsettle age-old tradition and structures that gradually give in to demands from NGOs and social movements. Such popular agitation from below underlines the transition from transgressive to insurgent citizenship. ${ }^{3}$

It is tempting at this stage to begin to theorise what could happen if this transition becomes the norm in contemporary Africa. Suffice it to note here that such a transition is already taking place in South Africa and Nigeria - two countries in Africa where this urban unsettling is arguably far advanced. Julian Brown (2015: 6) elaborates on this transition - from transgressive to insurgency citizenship - in South Africa by evoking the existence of two models of citizenship - 'one respectable, and founded on the willingness of citizens to participate, and the other disreputable, and insurgent'. The strategies employed by these insurgent movements in South Africa include public protests sanctioned by law-The Regulations of Gatherings Act-which state officials distort by using extra-legal powers to criminalise political expression. Pushed to the wall, popular movements, or 'insurgent citizens' in Brown's formulation, have either aligned themselves with NGOs who occasionally 'provide legal representation' or 'engage in parliamentary and electoral politics' (Brown 2015: 9). The emergence of Abahlali BaseMjondolo, ${ }^{4}$ a shack dwellers' organisation in Kwazulu Natal, is representative of the new kind of movements that are transitioning from transgressive to insurgent citizenship.

Abahlali BaseMjondolo (ABM) emerged in 2005 as a response against the highhanded action by state officials against shack dwellers around Kennedy Road in Durban, Kwa-Zulu Natal Province (Brown 2015; Gill 2014). Animated by popular national issues central to the existence of South Africa's wretched of the earthland, housing, basic services, and the dignity of the deprived - the movement quickly gained traction as it sought to confront violence from above and the absence of municipal governance in Durban. The movement echoed some of the issues around the provision of water services, connection and disconnection, that had gripped Umlazi township discussed in this special issue (see Mottiar 2021). Arguably, the emergence of popular community-based bottom-up movements in South Africa were a direct fallout from the promises made by the African National Congress, which has ruled South Africa since 1994. A million houses was what the ANC promised South Africa's unhoused and shack dwellers in its first term. The goal of completely eradicating slums and informal settlements would be achieved by the end of its fourth term (Gill 2014: 212).

\footnotetext{
${ }^{3}$ See the following on social movements in Africa: Mamdani \& Wamba-dia-Wamba (1995); Beinin \& Vairel (2012); Sylla (2014); Paret et al. (2018).

${ }^{4}$ Abahlali BaseMjondolo is a Zulu word meaning 'people who stay in shacks'.
} 
The failure of the ANC to deliver on the housing front together with the constant intimidation and harassment of its members pushed the ABM to experiment with electoral boycott. In a situation where the ruling ANC was a de-facto one-party state, electoral boycott could have been embraced as a mark of anger in the face of their extreme powerlessness to vote the government out of power. As a popular mobilising tool, the slogan 'No Land! No House! No Vote!' could have attracted a massive '99 per cent of nearly thirty thousand local residents' to abstain in the 2006 elections (Dwyer \& Zeilig 2012). This in itself does not translate to any substantial win in their favour, but it does suggest the new ways that bottom-up movements were beginning to think and act in their quest for a meaningful alternative to a government not responsive to their basic needs in a supposedly democratic state.

The sustained assault on its membership and leadership - incessant arrests and lawsuits for alleged murder - did not dampen the resolve of the ABM movement or lead it to abandon its principled campaign of electoral boycott. In 2008 they took a bold organisational stride by setting up an office in the Western Cape - the seat of the biggest opposition to the ANC government. From their base in Durban and Cape Town, the movement affirmed its commitment to continuous boycott of local and national elections. 'We are not fooled by party politics. We are very well aware that party politics is a battle between different factions of the elite. ... We remain determined to reject party politics and to build the power of the poor from the ground up' ('Abhalali Western Cape, cited in Brown 2015: 121). Three years later, on the eve of national and provincial elections, the movement would abandon election boycott and declare its support for the opposition Democratic Alliance in Zwa-Zulu Natal. Support for the opposition party, the DA, against the hegemonic ANC would eventually open the democratic space, paving the way for coalition and alliance politics at both local and national levels.

Of the four countries covered in this special issue, South Africa is arguably among the most, if not the most, democratic. But that democracy, which allows for regular free and fair elections, unlike Congo and Somalia, remains trapped in a post-Apartheid trajectory that has made it impossible for the ruling party to deliver on its successive electoral promises. This failure to deliver key dividends of democracy has triggered organised and spontaneous mass movements from below. The emergence of such insurgent movements in a supposedly functioning democracy raises fundamental questions about liberal democracy and the space it accords marginal citizens furthering their individual and collective interests. If an insurgent social movement could coalesce around the dire need for decent housing, then evolve to demand land, and from there graduate to politics by electing to stay away or throw in their support for the opposition, how functional is that democracy? Perhaps there is something to be learned here, namely, that 'social movements are an integral part of functioning 
democracies because democratic regimes often do not function well' (Johnston 2014: 159).

\section{Conclusion}

The OECD has rightly noted the critical need of 'tailored policies connected to the realities of urban Africa' (OECD 2020: 4); this issue brings some of these realities to light in the hope that greater understanding will lead to better responses to associated challenges. In doing so, it asks us to be wary of broad-brush strokes when using such terms as 'urban Africa', given the importance of local context and the variety of actors and aspects involved across the continent's many different cities. Nevertheless, key themes emerge across the articles of this special issue that, taken together, underline that Africa's urban populations share many similar challenges around contested citizenship and marginality. What citizenship constitutes, and where the boundaries lie between formal and informal, legal and illegal, state and non-state, are called into question. In many instances, subversion of the law has become a normative pathway to a form of insurgent citizenship. This subversion is not solely the action of those at the margins, coming from the direction of 'below'. Rather, this issue shows that we must understand how elites, and those in positions of formal power and authority, are complicit in the creation of informal urban (dis)orders. By extension, a common finding is that simple binaries that split urban actors between 'state' and 'non-state' fail to grasp the interlinkages between those who may on the surface appear in opposition: the street gang and the police, the criminal and the lawmaker. Nevertheless, we must understand the degree to which transgression of law and order in African cities does engender protest, resistance, and counter conduct. Even those who seek incorporation into an existing system through transgressive means, rather than seeking revolution, are in many respects engaged in a critique of that system and its exclusionary nature.

The everyday precarity which those on the urban margins face in the DRC, Ghana, Somalia, and South Africa is undeniable. And it points in no uncertain terms to the limitations of treating urban Africa's problems as fundamentally those of urban growth alone, as technical problems resolved by greater technological and developmental progress. Rather, at the heart of the issue lies the deeply entrenched political and economic structural inequalities that have shaped and continue to shape the landscape of the modern African city, as across much of the Global South. To address the insecurity of those who have been left behind by urban growth, those masses on the margins dwelling in informal settlements, it is necessary to address how those at the 'top'-locally and globally - play central roles in perpetuating and exploiting urban insecurity. In short, only through political change can there be real transformation of Africa's growing cities into engines of progress for all. 


\section{References}

Abdullah, I. (2020), 'Marginal Youths or Outlaws: Youth Street Gangs, Globalisation, and Violence', African Development, 45(3): 33-52.

Armano, E., Bove, A. \& Murgia, A. (eds) (2017), Mapping Precariousness, Labour Insecurity and Uncertain Livelihoods (London, Routledge).

Bates, R. (1999), 'The Economic Basis of Democratisation', in R. Joseph (ed.), State, Conflict, and Democracy in Africa (Boulder CO and London, Lynne Rienner).

Bayat, A. (1997), Street Politics: Poor Peoples Movements in Iran (New York, Columbia University Press).

Bayat, A. (2010), Life as Politics: How Ordinary People Change the Middle East (Stanford CA, Stanford University Press).

Beinin, J. \& Vairel, F. (eds) (2012), Social Movements, Mobilization, and Contestation in the Middle East and North Africa (Stanford CA, Stanford University Press).

Bjarnesen, M. (2021), 'Agents of Urban (In)security: Contextualising the Banning of Political Vigilantism in Ghana', Journal of the British Academy, 9(s11): 19-39.

Brown, J. (2015), South Africa's Insurgent Citizens (London, Zed Books).

Chonka, P. \& Bakonyi, J. (2021), 'Precarious Technoscapes: Forced Mobility and Mobile Connections at the Urban Margins', Journal of the British Academy, 9(s11): 67-91.

Cooper, F. (1983), Struggle for the City: Migrant Labor, Capital, and the State in Urban Africa (Beverley Hills, Sage Publications).

Coquery-Vidrovitch, C. (1991), 'The Process of Urbanization in Africa (From the Origins to the Beginning of Independence)', African Studies Review, 34(1): 1-98.

Davis, M. (2006), Planet of Slums (London, Verso).

Diouf, M. (1999), 'Urban Youth and Senegalese Politics: Dakar 1988-1994', in J. Holston (ed.), Cities and Citizenship (Duke NC, Duke University Press), 42-66.

Dwyer, P. \& Zeilig, L. (2012), African Struggles Today: Social Movements Since Independence (Chicago IL, Hay Market Books).

Freund, B. (2007), The African City: A History (New York, Cambridge University Press).

Gandy, M. (2006), 'Planning, Anti-planning and the Infrastructure Crisis Facing Metropolitan Lagos', Urban Studies, 43(2): 371-96.

Gill, G. (2014), 'Knowledge Practices in Abahalali baseMjondolo', Interface: A Journal for and About Social Movements, 6(1): 211-29.

Hendriks, M. (2021), 'Imagining the Anti-gang: The State, the Father and Jean-Claude Van Damme', Journal of the British Academy, 9(s11): 41-65.

Holston, J. (ed.) (1999), Cities and Citizenship (Durham NC, Duke University Press).

Holston, J. (2008), Insurgent Citizenship: Disjunctions of Democracy and Modernity in Brazil (Princeton NJ, Princeton University Press).

Honwana, A. (2012), The Time of Youth: Work, Social Change, and Politics in Africa (Sterling VA, Kumarian Press).

Hove, M., Ngwerume, E.T. \& Muchemwa, C. (2013), 'The Urban Crisis in Sub-Saharan Africa: A Threat to Human Security and Sustainable Development', Stability: International Journal of Security and Development, 2(1): Art. 7.

Joseph, R. (ed.) (1999), State, Conflict, and Democracy in Africa (Boulder CO and London, Lynne Rienner).

Johnston, H. (2014), What is a Social Movement? (London, Polity Press).

Mabogunje, A. (1990), 'Urban Planning and the Post-Colonial State in Africa: A Research Overview', African Studies Review, 33(2): 121-203.

Mamdani, M. \& Wamba-dia-Wamba, E. (eds) (1995), African Studies in Social Movements and Democracy (Dakar, CODESRIA). 
Mitton, K. (forthcoming), 'A Game of Pain: Youth Marginalisation and the Gangs of Freetown', Journal of Modern African Studies.

Mkandawire, T. (1999), 'Crisis Management and the Making of “Choiceless Democracies”, in R. Joseph (ed.), State, Conflict, and Democracy in Africa (Boulder CO and London, Lynne Rienner).

Mottiar, S. (2021), 'Shaping a Township: Self-connecting as "Counter conduct" in Umlazi, Durban', Journal of the British Academy, 9(s11): 93-106.

OECD (2020), Africa's Urbanisation Dynamics 2020: Africapolis, Mapping a New Urban Geography (Paris, West African Studies, OECD Publishing).

Olajide, O.A., Agunbiade, M.E. \& Bishi, H.B. (2018) 'The Realities of Lagos Urban Development Vision on Livelihoods of the Urban Poor', Journal of Urban Management, 7(1): 21-31.

Paret, M., Runciman, C. \& Sinwell, L. (eds) (2018), Southern Resistance in Critical Perspective: The Politics of Protest in South Africa's Contentious Democracy (London, Routledge).

Princewill, N. (2021), 'Africa's Most Populous City is Battling Floods and Rising Seas. It May Soon be Unliveable, Experts Warn', CNN, 2 August 2021. https://edition.cnn.com/2021/08/01/africa/ lagos-sinking-floods-climate-change-intl-cmd/index.html

Salahub, J.E., Gottsbacher M. \& de Boer, J. (eds) (2018), Social Theories of Urban Violence in the Global South: Towards Safe and Inclusive Cities (London and New York, Routedge).

Scott, J.C. (1990), Domination and the Arts of Resistance: Hidden Transcripts (New Haven CT, Yale University Press).

Schnitzer, A.V. (2016), Democracy's Infrastructure: Techno-Politics and Protest after Apartheid (Princeton NJ and Oxford, Princeton University Press).

Simone, A.M. \& Abouhani, A. (eds) (2005), Urban Africa: Changing Contours of Survival in the City (Dakar, Zed Press).

Sylla, N. (ed.) (2014), Liberalism and Its Discontents: Social Movements in West Africa (Dakar, Rosa Luxemburg Foundation).

Thompson, E.P. (1993), Customs in Common: Studies in Traditional Popular Culture (New York, New Press).

UN DESA (2019) World Urbanization Prospects: The 2018 Revision, Department of Economic and Social Affairs Population Division (New York, UN).

Van de Walle, N. (1999), 'Globalisation and African Democracy', in R. Joseph (ed.), State, Conflict, and Democracy in Africa (Boulder CO and London, Lynne Rienner).

Verweijen, J. (2019), Violent Cities, Violent Society: Analyzing Urban Violence in the Eastern Congo (Nairobi and London, Rift Valley Institute), 55-56.

Vidal, J. (2018), 'The 100 Million City: Is 21st Century Urbanisation Out of Control?' The Guardian, 19 March 2018. https://www.theguardian.com/cities/2018/mar/19/ urban-explosion-kinshasa-el-alto-growth-mexico-city-bangalore-lagos.

Warah, R. (2011), 'Afro-Pessimism in the Discourse on Urban East Africa', Development, 54(3): 325-9.

Young, C. (1999), 'The Third Wave of Democratisation in Africa: Ambiguities and Contradictions', in Joseph (1999).

To cite the article: Kieran Mitton and Ibrahim Abdullah (2021), 'Citizenship, Marginality and Urban (In)security in Contemporary Africa: Introduction', Journal of the British Academy, 9(s11): 1-17.

DOI https://doi.org/10.5871/jba/009s11.001

Journal of the British Academy (ISSN 2052-7217) is published by

The British Academy, 10-11 Carlton House Terrace, London, SW1Y 5AH

www.thebritishacademy.ac.uk 